\title{
Faktor-Faktor yang Berhubungan dengan Pemberian ASI Eksklusif di Puskesmas Beru-Beru Kalukku Kabupaten Mamuju Sulawesi Barat
}

\author{
Satriani $^{1}$ Ashriady ${ }^{2}$ Dina Mariana ${ }^{3}$ \\ 1,2, 3 Jurusan Kebidanan Poltekkes Kemenkes Mamuju \\ Corresponding author: Ashriady
}

Email: ashriady.abumuadz@gmail.com

Received: January $6^{\text {th }}, 2019$; Revised: January $16^{\text {th }}, 2019$; Accepted: January $30^{\text {th }}, 2019$

\begin{abstract}
According to WHO research, breast milk contains antibody hormones, immune factors, and antioxidants so that babies survive at 6 months. The 2013 Riskesdas data shows that percent of Exclusive breastfeeding babies up to 6 months 38\%. In 2016, urging Exclusive Breastfeeding in Mamuju District $30.3 \%$, the highest Puskesmas in Simboro Subdistrict and the lowest in Buttuada Puskesmas Buttuada Subdistrict 8.9\%, Beru-Beru Health Center Kalukku District 7.5\% and Karama Health Center Kalumpang District $0 \%$. The purpose of the study was to determine the factors associated with exclusive breastfeeding in Beru-Beru Health Center, Mamuju Regency, West Sulawesi.This type of research is observational with a cross sectional study design. The time of research in July - November Year Population is mothers who have ages 7 - 12 months in the work area of Beru-Beru Health Center, the study sample was taken using a total sampling of 190 mothers.The results showed that there was a relationship between knowledge, attitudes, culture, the role of midwives, mother's work and IMD status with exclusive ASI assistance at Beru-beru Health Center. In the hypothesis of high risk, Exclusive breastfeeding for mothers who do not work, do IMD, have sufficient knowledge, good attitude and positive culture is $56 \%$. The role of midwives in providing motivation, increasing knowledge of mothers, families and families is expected to improve the culture and negative attitudes of mothers about Exclusive Breastfeeding.
\end{abstract}

Keyword:mother's knowledge; mother's attitude; role of midwife; exclusive breastfeeding

\section{Pendahuluan}

Dalam kajian WHO, yang melakukan penelitian sebanyak 3000 kali, bahwa ASI mengandung semua nutrisi yang diperlukan bayi untuk bertahan hidup pada 6 bulan petama, mulai hormon antibodi, faktor kekebalan, hingga antioksidan. Berdasarkan hal tersebut WHO kemudian mengubah ketentuan mengenai ASI eksklusif yang semula hingga 4 bulan menjadi 6 bulan.

Penelitian (Alamirew et al. 2017)di Ethiopia menunjukkan bahwa pengetahuan ibu pada penelitiantentang pemberian ASI Eksklusif masih rendah yaitu kurang dari tiga perempat responden memeberikan jawaban yang benar. Namun, sikap positif terhadap pemberian ASI Eksklusif lebih tiga perempat responden menjawab dengan sikap positif. Peneliti merekomendasikan kepada petugas kesehatan yang bekerja di klinik kesehatan Ibu dan
Anak untuk memberikan informasi yang sesuai tentang pemberian ASI Eksklusif.

Sebuah penelitian deskriptif kualitatif yang dilakukan oleh (Radzyminski \& Callister 2016) menyelidiki keyakinan, sikap dengan keputusan pemberian ASI dan susu formula menunjukkan bahwa para ibu memilih menyusui karena itu lebih sehat untuk bayi.Ini mungkin merupakan refleksi dari konsep moralitas keibuan yang diidentifikasi oleh Knaak (2010) dan dicontohkan dalam penelitian Ludlow et al. (2012).

Dalam buku Prasetyo DS (2012) UNICEF berpendapat bahwa ASI ekslusif dapat menekan angka kematian bayi di Indonesia. UNICEFmenyatakan bahwa 30.000 kematian bayi di Indonesia dan 10 juta kematian anak balita di Indonesia setiap tahun bisa dicegah melalui pemberian ASI ekslusif selama 6 bulan sejak jam pertama setelah kelahirannya tanpa memberikan makanan dan minuman tambahan kepada bayi. 
Data yang didapatkan dari Dinas Kesehatan Propinsi Sulawesi Barat melalui survey awal yang dilakukan peneliti adalah pada tahun 2014 cakupan ASI Ekslusif dikabupaten Mamuju tergolong dalam angka yang paling rendah diantara enam Kabupaten yang ada di Propinsi Sulawesi barat, yaitu 39,9 \%. Untuk Kabupaten Majene 48,4\% , Polewali Mandar 58,6\%, Mamasa 41,2\%, Mamuju Utara 90,5\% dan, Mamuju Tengah 43,5\%. Di tahun 2015 cakupan ASI Ekslusif untuk Kabupaten Mamuju sebesar 30,5\%.

Untuk tahun 2016 data cakupan ASI Ekslusif di kabupaten Mamuju 30,3\% dimana cakupan tertinggi di Puskesmas Botteng Kecamatan Simboro dan 3 Kecamatan dengan cakupan terendah yaitu di Puskesmas Buttuada Kecamatan Buttuada 8,9\%, Puskesmas Beru-Beru Kecamatan Kalukku 7,5\% dan Puskesmas Karama Kecamatan Kalumpang 0\%.

\section{Metode Penelitian}

Jenis penelitian yang digunakan adalah observasional dengan desain cross sectional study.Penelitian ini dilaksanakan di Wilayah Kerja Puskesmas Beru-BeruKecamatan Kalukku Kabupaten Mamuju Propinsi Sulawesi Barat.Waktu penelitian dilaksanakan pada Bulan Juli - November Tahun 2017.

Populasi dalam penelitian ini adalah ibu yang memiliki sampai usia $7-12$ bulan yang ada di wilayah Puskesmas Beru-Beru Kabupaten Mamuju. Sampel penelitian diambil dengan menggunakan metode Total Sampling dengan jumlah sampel 190 ibu yang memiliki bayi $7-12$ bulan berdasarkan data dari Puskesmas Beru-Beru.

Penelitian ini telah mendapat persetujuan dari komisi etik penelitian kesehatan Polteknik Kesehatan Makassar No: 267/KEPKPTKMKS/VI/2017.

\section{Hasil dan Pembahasan}

\section{Karakteristik Responden}

Hasil penelitian ini menunjukkan bahwa kategori umur dengan frekuensi yang tertinggi adalah responden berumur antara $21-35$ tahun sebanyak 154 responden $(81,1 \%)$ yang merupakan kelompok usia produktif secara reproduksi. Berdasarkan tingkat pendidikan responden dapat dikatakan cukup tinggi, dimana sebagian besar responden memiliki tingkat pendidikan tamat SMA yaitu sebanyak 56 responden $(29,5 \%)$.
Berdasarkan penghasilan keluarga dengan frekuensi yang tertinggi adalah responden yang penghasilan keluarganya $<1.000 .000$ sebanyak 159 responden $(83,7 \%)$. Berdasarkan penolong persalinan, menunjukkan bahwa sebagian besar responden ditolong oleh bidan saat bersalin sebanyak $158 \quad(83,1 \%)$ dan selebihnya ditolong oleh dokter sebanyak 19 responden $(10 \%)$ dan oleh dukun sebanyak 13 responden $(6,8 \%)$. Untuk lebih jelas dapat dilihat dalam tabel 1 berikut:

\section{Tabel 1}

Distribusi Responden berdasarkan Umur Ibu, Pendidikan Ibu, Penghasilan Keluarga dan Penolong Persalinan di Wilayah Kerja Puskesmas Beru-BeruKabupaten Mamuju

\begin{tabular}{lll}
\hline Karakteristik & n & \% \\
\hline Umur Ibu & 15 & 7,9 \\
a. $<20$ Tahun & 154 & 81,1 \\
b. $21-35$ Tahun & 21 & 23,5 \\
c. > 35 Tahun & $\mathbf{1 9 0}$ & $\mathbf{1 0 0}$ \\
\hline Jumlah & & \\
\hline Pendidikan Ibu & 6 & 3,2 \\
a. Tidak sekolah & 13 & 6,8 \\
b. Tidak tamat SD & 49 & 25,8 \\
c. Tamat SD & 44 & 23,2 \\
d. Tamat SLTP & 56 & 29,5 \\
e. Tamat SMU & 22 & 11,6 \\
f. Tamat PT & $\mathbf{1 9 0}$ & $\mathbf{1 0 0}$ \\
\hline Jumlah & & \\
\hline Penghasilan Keluarga & 159 & 83,7 \\
a. $<1.000$. 000 & 31 & 16,3 \\
b. $\geq 1.000 .000$ & $\mathbf{1 9 0}$ & $\mathbf{1 0 0}$ \\
\hline Jumlah & & \\
\hline Penolong Persalinan & 158 & 83,1 \\
a. Bidan & 19 & 10,0 \\
b. Dokter & 13 & 6,8 \\
c. Dukun & $\mathbf{1 9 0}$ & $\mathbf{1 0 0}$ \\
\hline Jumlah & & \\
\hline
\end{tabular}

Berdasarkan tabel 2. diperoleh hasil penelitian bahwa dari 84 responden yang memberikan ASI Esklusif pada bayinya terdapat 53 responden $(54,1 \%)$ yang memiliki pengetahuan cukup sedangkan yang memiliki pengetahuan yang kurang hanya sebanyak 31 responden $(33,7 \%)$, dan dari 106 responden yang tidak memberikan ASI Esklusif pada bayinya sebagian besar memiliki pengetahuan yang kurang sebanyak 61 responden $(66,3 \%)$. Berdasarkan hasil analisis statistik dengan chi-square diperoleh nilai $p=0,00(p<\alpha=0,05)$. Hal ini berarti bahwa ada hubungan antara Pengetahuan dengan pemberian 
ASI esklusif di Puskesmas Beru - Beru tahun 2017.

Dari 84 responden yang memberikan ASI Esklusif pada bayinya sebagian besar memiliki sikap yang baik sebanyak77 responden $(53,1 \%)$ sedangkan yang memiliki sikap dengan kategori kurang hanya sebanyak 7 responden $(15,6 \%)$, dan dari 106 responden yang tidak memberikan ASI Esklusif terdapat 68 responden $(46,9 \%)$ memiliki sikap baik dan yang memiliki sikap dengan kategori kurang sebanyak 38 responden $(84,4 \%)$. Berdasarkan hasil analisis statistik dengan chisquare diperoleh nilai $\mathrm{p}=0,000(\mathrm{p}<\alpha=0,05)$. Hal ini berarti bahwa ada hubungan antara sikap dengan pemberian ASI Esklusif di Puskesmas Beru beruKabupaten Mamuju tahun 2017.

Dari 84 responden yang memberikan ASI Esklusif pada bayinya sebagian besar memilikibudayayang positif sebanyak 73 responden $(54,1 \%)$ sedangkan yang memiliki budaya negatif hanya sebanyak 11 responden (20\%), dan dari 106 responden yang tidak memberikan ASI Esklusif terdapat 62 responden $(45,9 \%)$ memiliki budaya positif dan yang memiliki budaya negatif sebanyak 44 responden (80\%).Berdasarkan hasil analisis statistik dengan chi-square diperoleh nilai $\mathrm{p}=0,000$ $(p<\alpha=0,05)$. Hal ini berarti bahwa ada hubungan antara budaya dengan pemberian ASI Esklusif di Puskesmas Beru - beruKabupaten Mamuju tahun 2017.

Dari 84 responden yang memberikan ASI Esklusif pada bayinya terdapat 47 responden (42,3 $\%)$ yang mendapat dukungan dari suaminya sedangkan responden yang kurang mendapat dukungan dari suaminya sebanyak 37 responden (48,6\%), dan dari 106 responden yang tidak memberikan ASI Esklusif terdapat 42 responden $(53,2 \%)$ yang kurang mendapat dukungan dari suaminya.Berdasarkan hasil analisis statistik dengan chi-square diperoleh nilai $\mathrm{p}=0, \quad 556$ $(p>\alpha=0,05)$. Hal ini berarti bahwa tidak ada hubungan antara dukungan suami dengan pemberian ASI Esklusif di Puskesmas Beru beruKabupaten Mamuju tahun 2017.

Dari 84 responden yang memberikan ASI Esklusif, sebagian besar mendapat dukungan dari bidan dalam memberikan ASI Esklusif pada bayinya sebanyak 59 responden $(55,7 \%)$ yang sedangkan responden yang kurang mendapat dukungan dari bidan hanya sebanyak 25 responden
$(29,8 \%)$, dan dari 106 responden yang tidak memberikan ASI Esklusifsebagian besar kurang mendapat dukungan dari bidan sebanyak59 responden (70,2\%). Berdasarkan hasil analisis statistik dengan chi-square diperoleh nilai $\mathrm{p}=0,000$ $(\mathrm{p}<\alpha=0,05)$. Hal ini berarti bahwa ada hubungan antara peran bidan dengan pemberian ASI Esklusif di Puskesmas Beru - beruKabupaten Mamuju tahun 2017.

Dari 84 responden yang memberikan ASI Esklusif, sebagian besar responden tidak bekerja sebanyak 73 responden $(48,7 \%)$ sedangkan responden bekerja hanya sebanyak 11 responden $(27,5 \%)$, dan dari 106 responden yang tidak memberikan ASI Esklusifterdapat 29 responden $(72,5 \%)$ yang bekerja. Berdasarkan hasil analisis statistik dengan chi-square diperoleh nilai $\mathrm{p}=0,020$ $(p<\alpha=0,05)$. Hal ini berarti bahwa ada hubungan antara pekerjaan dengan pemberian ASI Esklusif di Puskesmas Beru - beruKabupaten Mamuju tahun 2017.

Dari 84 responden yang memberikan ASI Esklusif pada bayinya, sebagian besar responden melakukan IMD setelah persalinan sebanyak 65 responden (53,3 \%)sedangkan responden yang tidak melakukan IMD hanya sebanyak 19 responden (27,9\%), dan dari 106 responden yang tidak memberikan ASI Esklusifterdapat 49 responden $(72,1 \%)$ yang tidak melakukan IMD setelah persalinan. Berdasarkan hasil analisis statistik dengan chi-square diperoleh nilai $\mathrm{p}=0,001$ $(p<\alpha=0,05)$. Hal ini berarti bahwa ada hubungan antara status IMD dengan pemberian ASI Esklusif di PuskesmasBeru-beruKabupaten Mamuju tahun 2017.

Pada hipotesis yang berisiko tinggi, probabilitas pemberian ASI Esklusif pada mereka yang tidak bekerja, melakukan IMD, memiliki pengetahuan yang cukup, sikap yang baik dan budaya yang positif adalah $56 \%$. Padahipotesis yang berisiko rendah, probabilitas pemberian ASI Esklusif hanya sebesar $44 \%$. 
Tabel 2

Hubungan Pengetahuan Ibu, Sikap Ibu, Budaya Ibu, Dukungan Suami, Peran Bidan, Pekerjaan Ibu dan Status IMD terhadap pemberian ASI Esklusif di Wilayah Kerja Puskesmas Beru-Beru Kabupaten Mamuju Tahun 2017

\begin{tabular}{|c|c|c|c|c|c|c|c|}
\hline \multirow{3}{*}{ Variabel Penelitian } & \multicolumn{4}{|c|}{ Pemberian ASI Eksklusif } & \multirow{2}{*}{\multicolumn{2}{|c|}{ Total }} & \multirow{3}{*}{$\mathrm{p}$} \\
\hline & \multicolumn{2}{|c|}{ ASI Eksklusif } & \multicolumn{2}{|c|}{$\begin{array}{l}\text { Tidak ASI } \\
\text { Eksklusif }\end{array}$} & & & \\
\hline & $\mathrm{n}$ & $\%$ & $\mathrm{n}$ & $\%$ & $\mathrm{n}$ & $\%$ & \\
\hline \multicolumn{8}{|l|}{ Pengetahuan Ibu } \\
\hline Cukup & 53 & 54,1 & 45 & 45,9 & 98 & 100 & \multirow{2}{*}{0,006} \\
\hline Kurang & 31 & 33,7 & 61 & 66,3 & 92 & 100 & \\
\hline \multicolumn{8}{|l|}{ Sikap Ibu } \\
\hline Baik & 77 & 53,1 & 68 & 46,9 & 145 & 100 & \multirow{2}{*}{0,000} \\
\hline Kurang & 7 & 15,6 & 38 & 84,4 & 45 & 100 & \\
\hline \multicolumn{8}{|l|}{ Budaya Ibu } \\
\hline Positif & 73 & 54,1 & 62 & 45,9 & 135 & 100 & \multirow{2}{*}{0,000} \\
\hline Negatif & 11 & 20,0 & 44 & 80,0 & 55 & 100 & \\
\hline \multicolumn{8}{|l|}{ Dukungan Suami } \\
\hline Mendukung & 47 & 42,3 & 64 & 57,7 & 111 & 100 & \multirow{2}{*}{0,556} \\
\hline Kurang Mendukung & 37 & 46,8 & 42 & 53,2 & 79 & 100 & \\
\hline \multicolumn{8}{|l|}{ Peran Bidan } \\
\hline Mendukung & 59 & 55,7 & 47 & 44,3 & 106 & 100 & \multirow{2}{*}{0,000} \\
\hline Kurang Mendukung & 25 & 29,8 & 59 & 70,2 & 84 & 100 & \\
\hline \multicolumn{8}{|l|}{ Pekerjaan Ibu } \\
\hline Tidak Bekerja & 73 & 48,7 & 77 & 51,3 & 150 & 100 & \multirow{2}{*}{0,020} \\
\hline Bekerja & 11 & 27,5 & 29 & 72,5 & 40 & 100 & \\
\hline \multicolumn{8}{|l|}{ Status IMD } \\
\hline IMD & 65 & 53,3 & 57 & 46,7 & 122 & 100 & \multirow{2}{*}{0,001} \\
\hline Tidak IMD & 19 & 27,9 & 49 & 72,1 & 68 & 100 & \\
\hline
\end{tabular}

Tabel 3 menunjukkan bahwa variabel pengetahuan, budaya, sikap, status IMD, dan pekerjaan merupakan faktor yang paling berpengaruh terhadap pemberian ASI Esklusif di Wilayah Kerja Puskesmas Beru-Beru Kabupaten Mamuju Tahun 2017. Berdasarkan analisis multivariat yang dilakukan dengan menggunakan uji regresi berganda logistik, dapat dijelaskan bahwa variabel yang berhubungan dengan pemberian ASI Esklusif adalah pengetahuan, budaya, sikap, status IMD, dan pekerjaan. Selanjutnya persamaan regresi logistik yang telah dimiliki, yaitu :

$\mathrm{Y}=-2,976+-0,841_{(\text {Pekerjaan })+0,801}$ (Status IMD) + $0,561_{\text {(pengetahuan) }}+1,457_{\text {(sikap) }}+1,232_{\text {(budaya) }}$

Berdasarkan persamaan regresi tersebut, dapat dihitung ramalan probabilitas Pemberian ASI Esklusif pada responden dengan karakteristik tertentu. Rumus yang digunakan untuk menentukan probabilitas pemberian ASI Esklusif $\mathrm{P}(\mathrm{X})=\frac{1}{1+\mathrm{e}-(\mathrm{y})}$

Apabila fungsi regresi di atas dimasukkan ke dalam rumus probabilitas pada hipotesis yang berisiko tinggi dalam memberikan ASI esklusif pada bayinya, yaitu adalah pekerjaan(1), status IMD (1), pengetahuan(1), sikap(1), dan budaya (1) maka akan menghasilkan persamaan regresi sebagai berikut:

$\mathrm{Y}=-2,976+-0,841(1)+0,801(1)+0,561$

$(1)+1,457(1)+1,232(1)$

$\mathrm{Y}=0,234$

$\mathrm{e}=2,7$ (Bilangan Natural)

Dengan demikian probabilitasnya adalah:

$\mathrm{P}(\mathrm{X})=\frac{1}{1+2,7-(0,234)}$

$\mathrm{P}(\mathrm{X})=\frac{1}{1+0,793}$

$\mathrm{P}(\mathrm{X})=0,56$ yaitu : 
Jadi Probabilitas pemberian ASI Esklusif pada mereka yang tidak bekerja, melakukan IMD, memiliki pengetahuan yang cukup, sikap yang baik dan budaya yang positif adalah $56 \%$. Apabila fungsi regresi logistik dimasukkan ke dalam persamaan pada hipotesis yang berisiko rendah dalam pemberian ASI Esklusif yaitu pada mereka yang bekerja (0), tidak melakukan IMD (0), memiliki pengetahuan yang kurang (0), sikap yang kurang (0)dan budaya yang negatif (0), maka probabilitas pemberian ASI Esklusif hanya sebesar $44 \%$.

Tabel 3

Hasil Analisis Regresi Berganda Logistik Faktor Pemberian ASI Esklusif di Wilayah Kerja Puskesmas Beru-Beru KabupatenMamujuTahun 2017

\begin{tabular}{llllccc}
\hline \multirow{2}{*}{ Variabel Penelitian } & \multirow{2}{*}{ B } & \multirow{2}{*}{ Wald } & \multirow{2}{*}{ Sign } & \multirow{2}{*}{ Exp $(\mathbf{B})$} & \multicolumn{2}{c}{ 95\% CI } \\
\cline { 6 - 8 } & & & & & LL & UL \\
\hline Pengetahuan & 0,561 & 2,739 & 0,098 & 1,752 & 0,902 & 3,405 \\
Sudaya & 1,232 & 8,963 & 0,003 & 3,427 & 1,530 & 7,674 \\
Statup & 1,457 & 9,629 & 0,002 & 4,295 & 1,711 & 10,782 \\
Pekerjaan & 0,801 & 4,983 & 0,026 & 2,229 & 1,103 & 4,504 \\
\hline Constant & $-0,841$ & 3,823 & 0,051 & 0,431 & 0,186 & 1,002 \\
\hline
\end{tabular}

\section{Hubungan Pengetahuan Ibu terhadap Pemberian ASI Eksklusif}

Hasil penelitian menunjukkan bahwa $52 \%$ responden memiliki pengetahuan tentang ASI Esklusif "cukup". Secara statistik variabel ini memiliki hubungan yang bermakna ketika dilakukan analisis bivariabel dengan nilaip value $=$ 0,006, sehingga pengetahuan ibu hamil tentang ASI Esklusif dianggap berpengaruh terhadap pemberian ASI Esklusif dibandingkan dengan yang memiliki pengetahuan tentang ASI Eksklusif "kurang".

Hasil yang sama ditujukkan (Fahriani et al. 2014), bahwa pengetahuan ibu yang benar mengenai ASI eksklusif didapatkan bermakna dengan pemberian ASI eksklusif. Dimana Tingginya proporsi ibu yang memiliki pengetahuan yang benar mengenai ASI ekslusif merupakan kontribusi dari beberapa faktor, seperti efektifnya edukasi mengenai ASI eksklusif secara umum di masyarakat, dan meningkatnya dukungan menyusui dari kelompok pendukung ASI (KPASI).

\section{Hubungan Sikap Ibu terhadap Pemberian ASI Eksklusif}

Hasil penelitian ini menunjukkan ada hubungan antara sikap dengan pemberian ASI Esklusif di Puskesmas Beru-Beru Kabupaten Mamuju tahun 2017. Hal tersebut sejalan dengan penelitian tentang pemberian ASI Eksklusif pada Bayi di Wilayah Kerja Puskesmas Kemaraya Kota Kendari yang menunjukkan pada hasil analisis uji statistik risk estimate dimana diperoleh nilai $\mathrm{p}$ value $=0,002$ nilai $\mathrm{OR}=5,220$. Angka tersebut memberikan makna bahwa terdapat pengaruh sikap terhadap pemberian ASI Eksklusif pada bayi usia 6 - 9 bulan di wilayah kerja Puskesmas Kemaraya Kota Kendari(Damayanty et al. 2015).

Hasil penelitian ini berbeda dengan penelitian hubungan antara pengetahuan, sikap dan kepercayaan ibu dengan Pemberian ASI Eksklusif di Wilayah Kerja Puskesmas Bonto Cani Kabupaten Bone tahun 2013 yang menunjukkan bahwa sebagian besar responden $(71,15 \%)$ memiliki sikap negatif terhadap ASI Eksklusif dan tidak terdapat hubungan yang bermakna antara sikap responden dengan pemberian ASI Eksklusif $(p=0,154)$ (Yuliana et al. 2013).

Berdasarkan penelitian yang dilakukan (Gibney et al. 2005)menyatakan bahwa banyak sikap dan kepercayaan yang tidak mendasar terhadap makna pemberian ASI yang membuat para ibu tidak melakukan ASI Eksklusif selama 6 bulan. Umumnya alasan ibu tidak memberikan ASI Eksklusif meliputi rasa takut yang tidak berdasar bahwa ASI yang dihasilkan tidak cukup atau memiliki mutu yang tidak baik, keterlambatan memulai pemberian ASI dan pembuangan kolostrum, teknik pemberian ASI yang salah, serta kepercayaan yang keliru bahwa bayi haus dan memerlukan cairan tambahan.

\section{Hubungan Budaya Ibu terhadap Pemberian ASI Eksklusif}

Penyebab rendahnya pemberian ASI Eksklusif selanjutnya adalah aspek budaya. Budaya memiliki peran yang sangat besar dalam 
pemberian ASI Eksklusif. Budaya yang dianut seseorang secara turun-temurun cendrung sulit untuk diperbaiki. Banyak kebudayaan di Indonesia yang menghambat pemberian ASI Eksklusif karena persepsi budaya (Pertiwi 2012). Hasil penelitian ini menunjukkan terdapat hubungan antara budaya dengan pemberian ASI Esklusif di Puskesmas Beru-BeruKabupaten Mamuju tahun 2017.

Hal ini sejalan dengan penelitian yang dilakukan di wilayah kerja Puskesmas Kuok Kabupaten Kampar tahun 2015 yang juga menunjukkan terdapat hubungan antara aspek budaya dengan pemberian ASI Eksklusif pada bayi usia $0-6$ bulan. Pada penelitian tersebut, peneliti berasumsi bahwa budaya berpengaruh terhadap rendahnya pemberian ASI Eksklusif, karena banyak ibu yang memberikan makanan tambahan kepada bayinya yang disebabkan kebiasaan turun temurun dalam keluarga dan kurangnya pendekatan dari tenaga kesehatan kepada tokoh masyarakat karena tokoh masyarakat lebih mudah untuk menyampaikan saran dan informasi kepada masyarakat dilingkungannya khususnya saran dan informasi tentang ASI Eksklusif kepada ibu-ibu yang menyusui (Hidayat 2016).

\section{Hubungan Dukungan Suami Terhadap Pemberian ASI Eksklusif}

Dalam penelitian ini, tidak terdapat hubungan antara dukungan suami dengan pemberian ASI Esklusif di Puskesmas BeruBeruKabupaten Mamuju tahun 2017. Menurut asumsi peneliti hal ini turut dipengaruhi oleh peran anggota keluarga yang lain selain suami. Keluarga adalah orang-orang terdekat ibu yang meliputi orang tua, mertua, dan saudara-saudara ibu.

Dukungan instrumental yang didapat dari keluarga terutama orang tua dan mertua ibu diantaranya adalah dengan memasakkan makanan yang dapat memperlancar ASI, seperti memasakkan sayur-sayuran. Ibu juga sering mendapatkan nasehat dari keluarga untuk memberikan ASI untuk bayinya yang merupakan wujud dari dukungan penilaian serta mendapatkan juga dukungan emosional berupa mendengarkan keluhan-keluhan ibu selama menyusui.

Dukungan dari keluarga mempunyai peran yang sangat besar dalam meyakinkan ibu untuk berperilaku menyusui eksklusif. Hal ini dikarenakan lokasi penelitian di daerah pedesaan dimana bentuk keluarga extended family masih banyak dijumpai. Dalam kondisi seperti ini, keputusan pola pengasuhan anak tidak hanya ditentukan oleh kedua orang tua tapi juga dipengaruhi oleh keluarga besarnya (Oktalina et al. 2015).

\section{Hubungan Peran Bidan Terhadap Pemberian ASI Esklusif}

Hasil penelitian ini menunjukkan bahwa ada hubungan antara peran bidan dengan pemberian ASI Esklusif di Puskesmas Beru-beruKabupaten Mamuju tahun 2017.Penelitian ini sejalan dengan penelitian yang dilakukan oleh (Aisyaroh 2005) yang meneliti tentang dukungan bidan dalam pemberian ASI Ekslusif di Desa Sumber Sari kecamatan Ngampel kebupaten Kendal bahwaada hubungan antara dukungan bidan dengan pemberian ASI eksklusif dimana uji statistik chisquare diketahui pvalue 0,037 nilai $\mathrm{P}<\alpha(0,05)$, ibu menyusui yang mendapat dukungan yang baik dari bidan maka akan memberikan ASI secara eksklusif yaitu 57,9\%dan ibu menyusui yang dukungannya kurang maka tidak memberikan ASI secara eksklusif yaitu 76,5\% dari 36 responden.

Ibu yang melahirkan di fasilitas kesehatan bisa mendapatkan bimbingan, arahan sehingga termotivasi untuk menyusui.Apabila ibu dan bayi mengalami kesulitan dalam pemberian ASI, petugas kesehatan dapat diharapkan membantu ibu sehingga pemberian ASI bisa berlanjut.Dalam penelitian ini ditemukan masih adanya ibu yang melahirkan di dukun sehingga peran bidan tidak maksimal dalam bimbingan pada ibu mengenai IMD sebagai langkah awal suksesnya ASI Ekslusif serta bimbingan tekhnik menyusui. Bila ibu memahami cara yang benar meletakkan bayinya pada posisi yang benar ketika menyusui, memahami pula waktu yang diinginkan oleh bayinya untuk menyusu, akan membuat ibu percaya diri karena mampu melakukan yang benar dalam memberikan ASI, maka berbagai hal yang menyulitkan (faktor penyulit) yang sifatnya umum, dapat dihindari atau dicegah. Oleh karena itu, disinilah letak salah satu dari peran bidan dalam mendukung pemberian ASI.

\section{Hubungan Pekerjaan Ibu Terhadap Pemberian ASI Esklusif}

Ibu yang tidak bekerja adalah ibu yang hanya menjalankan fungsinya sebagai ibu rumah tangga dan banyak menghabiskan waktunya di rumah tanpa terikat aktifitas lain atau pekerjaan diluar rumah, sehingga mempunyai kesempatan yang banyak untuk dapat merawat dan memberikan Air Susu Ibu(ASI) secara optimal 
tanpa dibatasi oleh waktu dan kesibukan(Juliastuti 2011). Hasil penelitian ini menunjukkan bahwa ada hubungan antara pekerjaandenganpemberian ASI Esklusif di Puskesmas Beru-beruKabupaten Mamuju tahun 2017.

Hal ini sejalan dengan penelitian yang dilakukan oleh Reskiandini Selvita Putri yang mengatakan bahwa ada hubungan pekerjaan ibu dengan pemberian ASI Eksklusif pada balita di posyandu bougenville desa gayaman kecamatan mojoanyar kabupaten mojokerto dimana lebih dari setengahnya ibu bekerja yang mempunyai balita tidak diberi ASI eksklusif 13 balita (46,4\%). Hasil penelitian dianalisis dengan melakukan uji Chisquare dan didapatkan nilai p sebesar 0,023 karena nilai $p<0,05$ yang berarti $\mathrm{H} 1$ diterima.

\section{Hubungan Inisiasi Menyusu Dini Terhadap Pemberian ASI Eksklusif}

Hasil penelitian menunjukkan bahwa ada hubungan antara status IMD dengan pemberian ASI Esklusif di Puskesmas Beru-beruKabupaten Mamujutahun 2017. Penelitian ini sejalan dengan penelitian yang dilakukan oleh (Aulia 2015) di Puskesmas Melati II Sleman Yogyakarta pada Tahun 2015 bahwa sebagian besar responden mendapatkan perlakuan IMD segera setelah melahirkan dengan durasi IMD lebih dari satu jam, yakni jumlah responden yang memberikan ASI eksklusif kepada bayinya adalah sebanyak 24 orang responden (80\%), sedangkan yang tidak memberikan ASI Eksklusif adalah sebanyak 6 orang responden (20\%). Hal ini menunjukan bahwa sebagian besar responden memberikan ASI eksklusif kepada bayinya, tanpa cairan maupun makanan tambahan apa pun hingga bayi berusia enam bulan.

Berbeda dengan penelitian yang dilakukan oleh (Agusvina 2015)di Posyandu Kelurahan Cempaka Putih Ciputat Timur yang mengatakan bahwa tidak ada hubungan IMD terhadap ASI Ekslusif dimana hasil uji statistiknya didapatkan nilai $\mathrm{p}=0,102$. Peneliti menyimpulkan dari hasil penelitian yang dilakukan pada tahun 2015 ini bahwa ibu tidak memberikan ASI Ekslusif disebabkan karena ibu yang tidak mengetahui manfaat ASI Ekslusif dan kriteria yang dikatakan ASI Ekslusif sehingga ibu cenderung memberikan makanan atau minuman tambahan kepada bayinya sebelum usia enam bulan.

\section{Simpulan}

Faktor-faktor yang berhubungan dengan pemberian Asi Eksklusif di Puskesmas Beru-Beru tahun 2017 adalah pengetahuan, sikap, budaya, peran bidan, pekerjaan ibu, status IMD. Sedangkan faktor-faktor yang tidak berhubungan dengan pemberian Asi Eksklusif di Puskesmas Beru-Beru tahun 2017 adalah dukungan suami.Peran bidan dimasyarakat dalam memberikan motivasi serta meningkatkan pengetahuan ibu, suami dan keluarga sehingga diharapkan dapat memperbaiki budaya yang negatif tentang ASI Ekslusif dan merubah sikap negatif ibu tentang ASI Ekslusif.Pendidikan kesehatan juga diberikan pada ibu yang bekerja tentang bagaimana ibu dapat terus memberikan ASI Ekslusif namun tetap bekerja.Selain peran bidan diperlukan juga adanya komitmen dari ibu untuk dapat memberikan ASI Ekslusif serta kerjasama dengan pemerintah setempat perihal penerapan peraturan pemerintah nomor 33 tahun 2012 tentang ASI Ekslusif.

\section{Daftar Pustaka}

Agusvina, R., 2015. Hubungan Inisiasi Menyusu Dini (IMD) terhadap Keberhasilan ASI Eksklusif di Posyandu Kelurahan Cempaka Putih Ciputat Timur. Universitas Islam Negeri Syarif Hidayatullah Jakarta. Available at: http://repository.uinjkt.ac.id/dspace/bitstrea m/123456789/28999/1/REVI AGUSVINAFKIK.pdf.

Aisyaroh, N., 2005. Dukungan Bidan dalam Pemberian Asi Eksklusif di Desa Sumbersari Kecamatan Ngampel Kabupaten Kendal. Available http://research.unissula.ac.id/file/publikasi/2 10104090/3581Dukungan_Bidan_dlm_ASI_ Eksklusif.pdf.

Alamirew, M.W. et al., 2017. Knowledge and Attitude towards Exclusive Breast Feeding among Mothers Attending Antenatal and Immunization Clinic at Dabat Health Center , Northwest Ethiopia: A Cross-Sectional Institution Based Study. Nursing Research and Practice, 2017.

Aulia, M.J., 2015. Hubungan IMD dengan Pemberian ASI Eksklusif pada Bayi Usia 612 Bulan di Puskesmas Mlati II Sleman Yogyakarta. Sekolah Tinggi Ilmu Kesehatan 'Aisyiyah Yogyakarta. Available at: https://www.academia.edu/16899754/Hubun gan_IMD_dengan_Pemberian_ASI_Eksklus 
if_Pada_Bayi_Usia_6-

12_Bulan_di_Puskesmas_Mlati_II_Sleman_

Yogyakarta.

Damayanty, S., Nurdianti \& Kamrin, 2015. Pemberian ASI Eksklusif pada Bayi di Wilayah Kerja Puskesmas Kemaraya Kota Kendari. Jurnal Kesehatan Masyarakat, 1(3), pp.1-5. Available at: https://id.scribd.com/document/391286773/s ri-damayanty-afiasi-vol1-no3-des-15-pdf.

Fahriani, R., Rohsiswatmo, R. \& Hendarto, A., 2014. Faktor yang Memengaruhi Pemberian ASI Eksklusif pada Bayi Cukup Bulan yang Dilakukan Inisiasi Menyusu Dini (IMD). Sari Pediatri, 15(6), pp.394-402.

Gibney, M.J., Kearne, J.M. \& Arab, L., 2005. Public Health Nutrition, Oxford: Blackwell Publishing.

Hidayat, R., $2016 . \quad$ Hubungan Pengetahuan,Pekerjaan dan Aspek Budaya terhadap Pemberian ASI Eksklusif pada Bayi Usia 0-6 Bulan di Wilayah Kerja Puskesmas Kuok Kabupaten Kampar Tahun 2015. Jurnal Kesehatan Masyarakat, 2(4), pp.8-19. Available at: http://journal.stkiptam.ac.id/index.php/kesm as/article/view/271.

Juliastuti, R., 2011. Hubungan Tingkat Pengetahuan, Status Pekerjaan Ibu, dan Pelaksanaan Inisiasi Menyusu Dini dengan Pemberian ASI Eksklusif. Universitas Sebelas Maret Surakarta. Available at: https://eprints.uns.ac.id/5255/1/2080910112 01110151.pdf.
Oktalina, O., Muniroh, L. \& Adiningsih, S., 2015. Hubungan Dukungan Suami dan Dukungan Keluarga dengan Pemberian ASI Eksklusif pada Ibu Anggota KP-ASI di Wilayah Kerja Puskesmas Megaluh Kabupaten Jombang. Media Gizi Indonesia, 10(1), pp.64-70. Available http://download.portalgaruda.org/article.php ?article $=467519 \&$ val $=8230 \&$ title $=$

Pertiwi, P., 2012. Gambaran FaktorFaktor yang Mempengaruhi Pemberian ASI Eksklusif di Kelurahan Kuncir Tangerang. Jurnal Keperawatan FIK UI.

Prasetyo DS, 2012. Buku Pintar ASI Eksklusif, Jogjakarta: Diva Press.

Radzyminski, S. \& Callister, L.C., 2016. Mother's Beliefs, Attitudes, and Decision Making Related to Infant Feeding Choices. The Journal of Perinatal Education, 25(1), pp.18-28. Available at: http://connect.springerpub.com/lookup/doi/1 0.1891/1058-1243.25.1.18.

Yuliana, N., Bahar, B. \& Salam, A., 2013. Relationship Between Knowledge, Attitudes, Andtrust of Mothers With Exclusive Breastfeeding in Health Community Center of Bonto Cani Working Area of Bone Regency 2013., pp.1-13. Available at: http://repository.unhas.ac.id/bitstream/handl e/123456789/5560/JURNAL.pdf. 